\title{
AN EXTRAORDINARY WOMAN: The Honorable Constance Baker Motley
}

\author{
(SEPTEMBER 9, 1921 - SEPTEMBER 28, 2005)
}

\section{Florence Wagman Roisman*}

The Honorable Constance Baker Motley was an extraordinary person and one of the noteworthy and surprising facts about her is how little has been written about her life and work. To learn more about her, one might read her autobiography, Equal Justice Under Law, ${ }^{1}$ and one might watch a videotape of a 1988 interview of her conducted by Alfred Aman, Professor and former Dean at the Indiana University Maurer School of Law. ${ }^{2}$

Here are several striking facts about Constance Baker Motley, any one of which would make her worthy of serious study. There were only four other women on the federal bench when she was appointed and she was the first black woman ever appointed. ${ }^{3}$ She served for almost twenty years, from 1946 to 1964 , as a staff attorney with the NAACP Legal Defense and Educational Fund, Inc. ("Legal Defense Fund" or "LDF") and was part of the "inner circle" responsible for Brown v. Board of Education, a case many consider to be the most important of the twentieth century. ${ }^{4}$ She represented James Meredith in his successful attempt to integrate the University of Mississippi-integration accomplished only with the intervention of federal troops. ${ }^{5}$ She "argued ten cases before the U.S. Supreme Court and won nine of them." She "may have been the first black

* This is a slightly revised version of a talk given by Professor Florence Wagman Roisman during Women's History Month at Indiana University Robert H. McKinney School of Law in 2004.

Professor Roisman is grateful to Faye Williams, Esq., Regional Attorney for the Equal Employment Opportunity Commission, whose request to use this speech at a Continuing Legal Education program prompted this revision, and to the Indiana Law Review for its interest in publishing this. Professor Roisman also thanks Richard Humphrey, Matthew Whitlock, and Mary R. Deer for research and editorial assistance.

Professor Roisman dedicates this article to her beloved daughter, Rachel Eleah Roisman, M.D., M.P.H., herself an extraordinary woman.

1. Constance Baker Motley, Equal Justice Under Law (Farrar, Straus \& Giroux 1998).

2. Interview by Alfred C. Aman with Judge Constance Baker Motley (1988).

3. Linn Washington, Black Judges on Justice 127-28 (The New Press 1994).

4. Michael J. Klarman, From Jim Crow to Civil Rights: The Supreme Court and the Struggle for Racial Equality vii (Oxford Univ. Press 2004) (stating Brown is "widely deemed to be the most important Supreme Court decision of the twentieth century"); RICHARD KLUGER, Simple Justice: The History of Brown v. Board of Education and Black America's STRUGGLe For EQuality 638 (Vintage Books 1977) (“inner circle”).

5. William Doyle, An American Insurrection: The Battle of Oxford, Mississippi, 1962, at 292 (Anchor Books 2001); WASHINGTON, supra note 3, at 128.

6. WASHINGTON, supra note 3 , at 128 . 
woman in modern times to argue before the Supreme Court;"' she certainly was one of the few women to make such arguments in the mid-twentieth century. Justice William O. Douglas wrote in his autobiography that Charles Hamilton Houston's mind "had as sharp a cutting edge as any I have known" and that Constance Baker Motley "was equal to Houston in advocacy of cases ... [T]he quality of [her] arguments would place her in the top ten of any group of advocates at the appellate level in this country." She was the first black woman, and only the second woman, elected to the New York State Senate and the first woman to serve as a New York City Borough President, in her case of Manhattan, and on the New York City Board of Estimate. ${ }^{9}$

Constance Baker Motley's parents immigrated to the United States from Nevis, a tiny island in the Eastern Caribbean, where their forebears had been slaves..$^{10}$ Her parents settled in New Haven, Connecticut, where Constance Baker was born and attended public schools. ${ }^{11}$ Her father was a cook and her mother was a housewife. ${ }^{12}$ Judge Motley was the ninth of twelve children. ${ }^{13}$ Her comments about her mother are particularly appropriate for consideration of women's history for they leave one wondering what her mother might have achieved had she lived at a time when women, white as well as black, were less restricted:

Everybody loved my mother. Even people who were not her relatives would come to her with their problems. When she died in 1973, hers was the second-biggest funeral the church ever had. . . . I think if my mother had had the opportunity she would have pursued her education and gone to college. She had that much intelligence and was that interested in government, community affairs, and people's lives. ${ }^{14}$

She also told a story about her mother that I found particularly moving:

I remember one day playing in front of the house with my sisters Eunice and Marion when a white man approached and asked to speak to our mother. We called for her, and when she came out, the white man asked if she could spare any food since he had not eaten for a while and was in search of work. This was about 1931. The man said he was trying to

7. MotLEy, supra note 1 , at 201.

8. William O. Douglas, The Court Years 1939-1975, at 185 (Random House 1st ed. 1980). For more information about Charles Hamilton Houston, a seminal figure in the Civil Rights Movement, see id. at 195; Genna Rae McNeil, Groundwork: Charles Hamilton Houston AND the Struggle for Civil Rights (Univ. of Pa. Press 1983).

9. WASHington, supra note 3 , at 127.

10. Motley, supra note 1 , at 9,14 .

11. Karen Berger Morello, The Invisible Bar: The Woman LaWyer in America 1638 to the Present 157 (Beacon Press 1986).

12. $I d$.

13. Id.

14. MotLey, supra note 1 , at 17. 
make it to Boston. I thought my mother would simply shoo him away with words like "I have too many children to feed." Instead, much to my surprise, she invited him to the back yard, where she directed him to sit on the porch. I realize now it was my mother's way of sheltering the man from the embarrassment of begging and eating in public. My mother went into the house and, as usual, found something in the icebox. We children watched the man gobble down whatever it was and then ask for a glass of water. We had learned in school about hoboes and vagabonds who roamed the country, but that was the first time I actually saw one. When the man left, I asked my mother why she had given him food, since he was white. She replied, "Because he was hungry."

From a young age, Constance Baker wanted to become a lawyer, but her family's financial situation made it impossible for her even to attend college. ${ }^{16}$ Her outspokenness and courage served her well, however, and provided the opportunity for her to achieve her dream. Late in 1940, after Constance Baker had graduated from high school, she took a job "varnishing chairs for a building reconstruction project." " She also was a community activist and served as President of the New Haven Negro Youth Council. ${ }^{18}$ At a meeting called to discuss the apparent lack of interest shown by the black community in opportunities provided by the Dixwell Community House, Constance Baker spoke out, saying "that all the people on the board [of the Community House] were from Yale, and, therefore, the black community had no real input into what was going on; they did not consider it their place, and so we did not have a mass response to the center." ${ }^{19}$ Constance Baker wrote later: "I was the only speaker who caused a stir." 20

As it happened, one person who attended the meeting was a white multimillionaire, Clarence W. Blakeslee, President of the New Haven Gas Company, the Water Company, and C.W. Blakeslee \& Sons; a founder of the Union Trust Company; and a philanthropist who had given a good deal of money to, among other things, Dixwell Community House. ${ }^{21}$ A day after the meeting at which Constance Baker "caused a stir," she was told Mr. Blackslee wished to see her. ${ }^{22}$ This is her account of what happened when she went to his office a few days later:

[Mr. Blakeslee] and I talked alone in his unpretentious office. He said, as best I can recall, "I was very impressed with what you had to say the other night. I looked up your high school record, and I see you graduated

15. Id. at 23 .

16. Id. at 45 .

17. Morello, supra note 11 , at 157 .

18. MotLey, supra note 1 , at 44 .

19. Id. at 45 .

20. $I d$.

21. Id. at 44 .

22. Id. at 45 . 
with honors. I want to know why you are not in college." Startled, I said, "I don't have the money to go to college. My parents do not have the money to send me to college." He asked, "What would you like to do?" I said, "I'd like to be a lawyer." With raised, truly bushy eyebrows, he said, "Well, I don't know much about women in the law, but if that's what you want to do, I'll be happy to pay your way for as long as you want to go. I am sending my grandson to Harvard Law School. I guess if I can send him to Harvard, I can send you to Columbia." Then he said, "Never be afraid to speak up; as Abraham Lincoln said, an independent voice is God's gift to the nation." 23

Judge Motley said when she went home and told this story to her parents, "[t]hey didn't much believe it. But they didn't oppose it. They had never encouraged me to become a lawyer. That was not in their dreams for me. They thought I should be a hairdresser." ${ }^{24}$ Thanks to Mr. Blakeslee, she did attend college, first Fisk University, then New York University. ${ }^{25}$ Judge Motley told of her trip to Fisk:

When the train got to Cincinnati, Ohio, which is on the border with Kentucky, an Old South state, I had to disembark while the train employees put another passenger car behind the engine. It was older and rustier than the other cars on the train. When I went to get back on, a black porter said to me: "You have to go in this car," pointing to the one that had just been added. It had a sign reading COLORED on the coach door inside. Although I had known this would happen, I was both frightened and humiliated. ${ }^{26}$

While at Fisk, she learned that

being black prevented her from attending the theater, eating in restaurants, and trying on clothing and shoes in department stores. "Colored women were expected to give their size and buy without trying on, so the clothing never touched you. After a couple of times I decided if I needed clothes, I would wait until I was back in New Haven; I wasn't going shopping in Nashville anymore."

Restricting herself almost exclusively to the Fisk campus and resenting it, Motley decided to transfer to a northern school. She signed up for courses at New York University and within two and a half years earned an honors degree in economics. ${ }^{27}$

23. Id.

24. J. Clay Smith JR., Rebels in Law: Voices in History of Black Women LaWyers 42 (Univ. of Mich. Press 1998).

25. Motley, supra note 1 , at 47, 53.

26. Id. at 47 .

27. MoRello, supra note 11 , at 159 . With respect to shopping, see MOTLEY, supra note 1, at 48 (stating she had bought all her "clothes and personal items in New Haven with money from 
After college, she was accepted at Columbia Law School. ${ }^{28}$ Mr. Blakeslee helped her purchase appropriate clothing and take public speaking courses during the summer. ${ }^{29}$ While at Columbia, in 1945, she began to work for the NAACP Legal Defense Fund and she continued to work there, as a staff attorney, after her graduation from Columbia in $1946 .^{30}$ Law students in particular may be interested to know that, at least in her third year, she found law school "an unmitigated bore, wholly theoretical, esoteric, and without practical application." ${ }^{31}$ There were no clinical or civil rights courses. ${ }^{32}$ As she wrote:

Clinical legal education had not yet been born, and civil rights litigation was virtually unknown. The few civil rights cases I heard about when growing up had been the catalyst for my interest in law in the first place. The LDF job was just what I needed and wanted. It was my first inkling that I was going to do something I wanted to with my legal education and my life. ${ }^{33}$

Judge Motley had an extraordinary docket at LDF. LDF litigated Sweatt $v$. Painter, the first case in which the Supreme Court ordered a black person admitted to a previously all-white educational institution - in this case, the University of Texas School of Law. ${ }^{34}$ Judge Motley worked on Ada Sipuel's successful attempt to attend the University of Oklahoma's law school and on Professor G.W. McLauren's successful attempt to escape the internal segregation (screens separating him from other students) at the Graduate School of Education of the University of Oklahoma. ${ }^{35}$ She participated in the suit to integrate Georgia State College of Business Administration in Atlanta - the first civil rights case LDF won in Georgia. ${ }^{36}$ She worked on the public school desegregation cases in Atlanta, Savannah, Brunswick, and Albany, Georgia ${ }^{37}$ and in Mobile, Alabama ("where," she writes, "everyone was ready for desegregation except the federal district judge, Daniel H. Thomas"). ${ }^{38}$ She represented not only James Meredith at Ole Miss, but also Autherine Lucy (and later Vivian Malone and James Hood) in their successful suits to integrate the University of Alabama and Charlayne

Mr. Blakeslee" and so "had no need to go shopping" and that "[s]ome stores allowed Fisk students to try on clothes, a deal negotiated by Mamie Foster, the dean of women.").

28. MotLey, supra note 1, at 56.

29. Morello, supra note 11 , at 159.

30. MotLey, supra note 1 , at 58.

31. Id. at 59 .

32. Id.

33. Id.

34. Id. at 63-65; see Sweatt v. Painter, 339 U.S. 629, 635 (1950).

35. MotLey, supra note 1, at 64-65; see Sipuel v. Bd. of Regents of Univ. of Okla., 332 U.S. 631, 633 (1948); McLaurin v. Okla. State Regents for Higher Educ., 339 U.S. 637, 642 (1950).

36. MotLey, supra note 1 , at 141.

37. Id. at 146 .

38. Id. at 147. 
Hunter (now Charlayne Hunter Gault) and Hamilton Holmes in their successful effort to integrate the University of Georgia. ${ }^{39}$ She later represented Harold Franklin in his attempt to desegregate Alabama's other flagship institution, Auburn Polytechnic Institute, now Auburn University ${ }^{40}$ and Harvey Gantt when he sought admission to Clemson College in $1962 .{ }^{41}$

While she was LDFs expert on these higher education cases, she handled many other issues as well, including Rice v. Elmore, a 1947 case successfully challenging the white primary in South Carolina.$^{42}$ She represented Dr. Martin Luther King, Jr., in Albany, Georgia and Birmingham, Alabama. ${ }^{43}$ She was the lawyer for 1081 Birmingham students suspended from school for having been arrested for participating in demonstrations ${ }^{44}$ She represented the students who "sat-in" in Maryland restaurants and took their case to the Supreme Court in Bell v. Maryland. ${ }^{45}$ (The lead plaintiff later became the Chief Judge of Maryland's highest court. ${ }^{46}$ ) She represented Freedom Riders. ${ }^{47}$ She worked on the case that desegregated "recreational facilities in the parks in Memphis," Tennessee. ${ }^{48}$

In the Law and Social Change course I teach, we consider the relative contributions to permanent change made by direct action, like the Montgomery Bus Boycott and the demonstrations in Birmingham, and legal action, like the lawsuit that ended the Montgomery Bus Boycott by holding segregation on local

39. See id. at 121-24, 145-46, 187; SMITH, supra note 24, at 43; see also Lucy v. Adams, 350 U.S. 1 (1955); Meredith v. Fair, 305 F.2d 343 (5th Cir. 1962); United States v. Wallace, 218 F. Supp. 290 (N.D. Ala. 1963); Holmes v. Danner, 191 F. Supp. 394 (M.D. Ga. 1961).

40. Franklin v. Parker, 223 F. Supp. 724 (M.D. Ala. 1963).

41. Gantt v. Clemson Agric. Coll., 320 F.2d 611 (4th Cir. 1963) (Harvey Gantt later became mayor of Charlotte, North Carolina, ran against Jesse Helms, and almost succeeded in replacing him in the U.S. Senate); MotLey, supra note 1, at 187-88; WAShIngton, supra note 3, at 139; see Topics of the Times; Race in North Carolina, N.Y. Times (Nov. 8, 1990), http://www.nytimes. com/1990/11/08/opinion/topics-of-the-times-race-in-north-carolina.html [https://perma.cc/BPF73JG7].

42. Motley, supra note 1, at 66; see Rice v. Elmore, 333 U.S. 875 (1948).

43. Glenn T. Eskew, But For Birmingham: The Local and National Movements in the Civil Rights Struggle 252, 254 (N.C. Press 1997); Motley, supra note 1, at 135-40; Morello, supra note 11, at 161 (Birmingham).

44. MotLey, supra note 1 , at 135-37.

45. Id. at 251; Bell v. Maryland, 378 U.S. 226 (1964).

46. See William L. Reynolds, Tributes to Chief Judge Robert M. Bell: The Life and Times of Chief Judge Robert Bell, 72 MD. L. REV. 1077, 1077 (2013).

47. MotLey, supra note 1 , at 167.

48. Washington, supra note 3, at 140; see Watson v. Memphis, 373 U.S. 526 (1963); see generally, regarding all these events, Taylor Branch's wonderful trilogy about the United States in the "King Years." Taylor Branch, Parting the Waters: America in the King Years 1954-63 (1989) [hereinafter Parting the Waters]; Taylor Branch, Pillar of Fire: America in the King Years 1963-65 (1998); TAYlor Branch, At CANAAn's Edge: AMERicA IN THE King Years 1965-68 (2006). 
buses unconstitutional. ${ }^{49}$ In this connection, it is worth noting Judge Motley's view that the lawsuit over the student suspensions was:

the most critical point in what we now call the Birmingham campaign. If Judge Tuttle had not held this extraordinary court session, Martin Luther King might have gone down in Birmingham. Instead, [Judge] Tuttle's injunction revitalized King's efforts. Yet there was not a single line the next day in the Birmingham papers or on the local radio station about the injunction. ${ }^{50}$

Constance Baker Motley appeared before the Fifth Circuit so frequently that Chief Judge Tuttle said once that "Mrs. Motley has been here so often I sometimes think she is a member of this court." ${ }^{51}$ In 1962, she argued four appeals in the Fifth Circuit in one day. ${ }^{52}$

One thing to which I really want to invite your attention is how much of a pioneer she was as a woman - before we even get to the fact of her being a black woman. Imagine what it was like for her as a woman, let alone as a black woman. At Columbia Law School, she found about twenty-three women in the entire law school. ${ }^{53}$ The dean of the law school reportedly had earlier voted against the admission of women to the law school ${ }^{54}$ and there was a "hard-nosed, antiwomen bias prevalent in the profession.... [But] Columbia Law School men were being drafted, and suddenly women who had done well in college were considered acceptable candidates for the vacant seats." ${ }^{55}$ Despite that hostile atmosphere, she said: "[T]he few women that were there nevertheless survived and graduated. When I graduated in 1946, you would not have been able to find a single person ready to bet twenty-five cents that I would be successful in the legal profession. I didn't believe it either." 56

Kristin Booth Glen, a former Dean of City University of New York Law School, who graduated from Columbia Law School in 1966, complained about what it was like at Columbia when she was there, almost twenty years after Judge Motley. ${ }^{57}$ Dean Glen has written: "When I entered Columbia in 1963 . . women made up less than seven percent of my class, and constituted only three percent of the profession. There were no women professors or senior administrators at

49. See Randall Kennedy, Martin Luther King's Constitution: A Legal History of the Montgomery Bus Boycott, 98 YALE L.J. 999 (1989); see also Gayle v. Browder, 342 U.S. 903 (1956).

50. MotLey, supra note 1 , at 137.

51. Id. at 140 .

52. WASHINGTON, supra note 3 , at 139.

53. MotLey, supra note 1, at 56.

54. Sмiтh, supra note 24 , at 42.

55. MotLey, supra note 1 , at 56.

56. SмITH, supra note 24, at 42; see also WASHINGTON, supra note 3, at 136 (expressing Judge Motley's sentiment upon graduation from Columbia).

57. Kristin Booth Glen, When and Where We Enter: Rethinking Admission to the Legal Profession, 102 Colum. L. REV. 1696, 1697 (2002). 
the Law School, as was generally true at law schools throughout the country." ${ }^{58}$

Judge Motley said that "if it had not been for Thurgood Marshall's liberal view of how women probably ought to have the same chance as men to become lawyers," she would not have been hired at LDF. ${ }^{59}$ And what was her job? Arguing cases in the federal courts. Very few women did that. As she says, she often was "the only woman in the courtroom . . . In the period 1949 to 1964, I tried school desegregation and other cases in eleven southern states and the District of Columbia and in that time I saw only one woman argue a case in the Fifth Circuit." ${ }^{\circ 0}$

I want to offer personal testimony to the drama of her achievements. I graduated from law school in 1963, almost twenty years after Constance Baker Motley - and it was considered weird for women to be in law school even then! (Harvard didn't admit women until 1950. ${ }^{61}$ ) Even when I was there, there were no tenured or tenure-track women professors or women administrators at the law school. (I believe one woman held a non-tenure track position created by the law school.) And women had a terrible time getting jobs after they graduated. I suppose everyone has heard the story about women law school graduates being asked how many words-per-hour they could type! When Judge Motley went on the bench in 1966, "women were not hired in the U.S. Attorney's Office on the criminal side." ${ }^{\prime 62}$ There were many other jobs not open to women in 1966.

For Constance Baker Motley, of course, the discrimination was more than doubled because she was both a woman and a black. As Jack Greenberg wrote, in the 1940s and 1950s, "[t]he social, economic, and political status of blacks was appalling. Everyday life was a constant affront." ${ }^{63}$ This was the experience when she and Thurgood Marshall went to hear Marshall and Charles Hamilton Houston argue the restrictive covenant cases:

Since Washington was a racially segregated town, we stayed in a socalled Negro hotel, which was no more than a rooming house in a residential area of brownstones. We had to have our meals at the rooming house as well because white restaurants did not serve blacks. . .. A moot court ... was held at Howard Law School the night before the Supreme Court arguments. We rode to the Supreme Court in cabs driven by black cabdrivers; white cabdrivers did not pick up blacks in $1947 .{ }^{64}$

With respect to traveling out of D.C., she remembered "being infuriated from

58. Id.

59. SMith, supra note 24 , at $42-43$.

60. Id. at 43 .

61. Herma Hill Kay, Ruth Bader Ginsburg: Law Professor Extraordinaire, 104 CoLUM. L. REV. 2, 7 (2004).

62. SMith, supra note 24 , at 45.

63. Jack Greenberg, Crusaders in the Courts: How a Dedicated Band of Lawyers Fought For the Civil Rights Revolution 36 (Basic Books 1st ed. 1994).

64. Motley, supra note 1, at 68; see Shelley v. Kraemer, 334 U.S. 1 (1948); Hurd v. Hodge, 334 U.S. 24 (1948). 
the top of my head to the tip of my toes the first time a screen was put around Bob Carter and me on a train leaving Washington in the 1940s." ${ }^{65}$ She and Robert Carter went to Mississippi in 1949 to try a teachers' salary equalization case. ${ }^{66}$ She told these stories about those ten days in Mississippi:

We could not stay at the white hotel in Jackson or eat in any white restaurant. We stayed in a rooming house operated by blacks, a large, white two-story framed building called a hotel, though it was in a residential area. These were typical accommodations for traveling black salesmen. Black visitors to Jackson and other places in the South usually stayed with relatives or friends, as we often did in our travels. ${ }^{67}$

Judge Motley reported such problems with accommodations continued until Congress enacted the Civil Rights Act of 1964, "making it possible for us to stay in white hotels and eat in white restaurants." 68

Accommodations were not the only challenge:

Before the trial began, we met with Judge Sidney Mize. Bob convinced him that counsel for the school board should address Gladys Bates as Mrs. Bates on the witness stand and refer to me as Attorney Motley. In 1949, there were few women lawyers in the United States and apparently none in Mississippi. My presence in Jackson thus added a quixotic dimension to the unusual challenge we were making. Judge Mize seemed incapable of saying "Mrs. Motley." He was the first person I ever heard say "Ms." During the trial, rather than refer to me as "Mrs. Motley, a visiting lawyer from New York," the local newspapers always called me "the Motley woman." There could have been no clearer statement of Mississippi's white-supremacist policy and practice. ${ }^{69}$

While in Mississippi for the same trial,

One of the most important features of the Mississippi teachers' salary case was that the trial took place in the federal district court in Jackson. When we arrived for the trial, the courtroom was packed-standing room only. The black citizens did not know that there was no racial segregation in a federal courthouse, only that in the state courts they had to sit in the balcony. Seeing no balcony in the federal courthouse, they

65. MotLey, supra note 1 , at 97.

66. Id. at 71 .

67. Id. at 73 .

68. WAShington, supra note 3, at 131. Of course, the 1964 Act did not solve all such problems. See, e.g., Samuel R. Bagenstos, The Unrelenting Libertarian Challenge to Public Accommodations Law, 66 StAn. L. Rev. 1205 (2014); see also Agreed Entry, United States v. Cracker Barrel Old Country Store, No. 4:04-CV-109-HLM (N.D. Ga. 2009), available at http://www.justice.gov/sites/default/files/crt/legacy/2010/12/14/cracker_agreed_order_5-18-09.pdf [https://perma.cc/85TJ-V5DL].

69. MotLey, supra note 1 , at 75. 
lined the walls, while all of the seats were taken by whites. After court that day, Bob Carter went to a local black barbershop for a haircut. Much to his surprise, he arrived to find the barbershop crowd watching one of its members imitate Bob's performance in the courtroom. The imitator had been enthralled by the fact that, at Bob's request, Judge Sidney Mize had directed the white superintendent of schools, who was then on the witness stand, to speak up so that Bob and the other lawyers could hear him. The barbershop crowd thought this was the greatest thing that had happened in Mississippi since the Emancipation Proclamation - that is, a white man being sharply questioned by a black man and then being made to speak up by another white man so that a black man could hear his answers. They had never seen anything like that before, nor had they seen any judge in Mississippi in this century consistently rule in favor of the black plaintiffs on motions and objections. Bob Carter introduced himself and explained to the group that there was no segregation in the federal courthouse, that blacks were free to sit anywhere they wished.

Once again, the courtroom was packed when we arrived at nine the next morning. Every seat was taken - but this time by blacks. ${ }^{70}$

In the federal courthouse, behind the judge's bench, in full view of counsel arguing to the

Court, was a mural showing:

not only the separation of the races but the inferior social status of blacks. On one side of the mural, white ladies in hoopskirts, frilly blouses, and silk bonnets are being escorted by tall, handsome white men in high silk hats and cutaway coats, standing next to a lavishly furnished horse-drawn carriage. It is a scenario right out of Hollywood's antebellum South. On the other side of the mural, black men in farmwork clothes and women with Aunt Jemima appearances, wearing aprons and bandannas, stand by stacks of baled cotton. ${ }^{71}$

Not surprisingly, Judge Motley found the mural "emotionally agonizing" and "disconcerting." "72

Constance Baker Motley joined the bar association in New York City. ${ }^{73}$ When she went to use its library, she was stopped at the entrance by a white "gatekeeper" who first ignored her while he conversed with another person and then refused her entry to the library because entrance was limited to members. ${ }^{74}$ She reported:

When I told him I was a member, it was as if he had seen a ghost. He

70. Id. at 75-76.

71. Id. at 76 .

72. Id.

73. GREENBERG, supra note 63 , at 36.

74. WASHINGTON, supra note 3, at 131. 
shouted in disbelief, "You are a member of this association?" He couldn't believe I was a member. There were only one or two other female members. Female members were so recent, there weren't even restrooms for us. The gatekeeper asked for my name and searched the membership list. When he found my name on the list, he said, "Oh, right this way, Constance." 75

Judge Motley attributed this to gender discrimination - which I find highly plausible, as I had a similar experience on my first use of the Supreme Court library and my first entrance into the section of the Supreme Court reserved for members of the Supreme Court Bar. Jack Greenberg told the same story about Constance Baker Motley and the bar association, but cited it as an instance of racial discrimination. ${ }^{76} \mathrm{He}$ adds - as Judge Motley does not- that she rebuked the doorkeeper for using her first name, asserting her name was Mrs. Motley. ${ }^{77}$ She had to correct people about this on many occasions. ${ }^{78}$

She frequently encountered discrimination on the job from other counsel and from judges. ${ }^{79}$ She reported when she first argued the Autherine Lucy case in the Fifth Circuit, one member of the panel, Louis W. Strum of Jacksonville, Florida, "swung his chair around and sat with his back to" her. ${ }^{80}$ She wrote that federal District Judge Marion Speed Boyd, in Memphis, always set Blacks' cases last on his calendar and usually closed his eyes when black lawyers spoke. ${ }^{81}$

In her work for LDF, Constance Baker Motley encountered not only discrimination, but considerable danger. ${ }^{82}$ When she and Thurgood Marshall went to Birmingham to argue a contempt hearing against the board of trustees of the University of Alabama, since they could not stay in a hotel or motel in Birmingham, they stayed in the home of black attorney Arthur Shores, whose "home had been bombed over a dozen times. ${ }^{83}$ "At night," she reported, they "were guarded by Black men with [shotguns and $\left.{ }^{84}\right]$ machine guns, and during the day we were escorted to and from court by men who carried handguns." 85 Constance Baker Motley wrote that the guns "sent shivers up my spine," and she could not sleep. "Fortunately," she wrote coolly, "when one is young, missing a night's sleep is easy." ${ }^{\text {" } 7 ~ W h e n ~ M e d g a r ~ E v e r s-w h o ~ l a t e r ~ w a s ~}$

75. $I d$.

76. GREENBERG, supra note 63 , at 36 .

77. Id.

78. See, e.g., MotLey, supra note 1 , at 167.

79. See, e.g., id. at 121.

80. Id.

81. Id. at 144 .

82. See id. at 123.

83. WAShington, supra note 3, at 137.

84. MotLey, supra note 1, at 123.

85. WASHINGTON, supra note 3, at 137.

86. MotLey, supra note 1 , at 123.

87. Id. 
assassinated $^{88}$ - drove her and her secretary from Jackson, Mississippi to Meridian, Mississippi for a hearing in the Meredith case, they were followed by state troopers, a terrifying ride followed by a night during which they expected to be attacked in the home of the courageous black family that agreed to shelter them for the night. ${ }^{89}$

Judge Motley's customary avoidance of complaints against co-workers is breached only slightly even with respect to what I suspect was perhaps the major disappointment in her career: the fact that when Thurgood Marshall was appointed to the Second Circuit, she was not his successor at LDF. As she put it, she "had been passed over for the top spot at LDF." ${ }^{90}$ Robert Carter, who had been Thurgood Marshall's first assistant, had become General Counsel to the NAACP when the NAACP and LDF separated in 1956. ${ }^{91}$ Marshall selected Jack Greenberg to head LDF, apparently in part because Marshall believed Constance Baker Motley had supported Robert Carter in the Carter-Marshall rift (which she says was not the case) and because, Constance Baker Motley said, "Thurgood also had difficulty with the idea of a woman in a leadership role in a male world." 92 She wrote: "The women's rights movement of the 1970s had not yet emerged. Except for Bella Abzug, I had no women supporters." 93

When she became the first woman (and the first black woman) appointed to the United States District Court for the Southern District of New York, there were only four other women on the federal bench-Florence Allen on the Sixth Circuit, Burnita Shelton Matthews on the District of Columbia district court, Sarah Hughes on a district court in Texas, and Mary Donlon on the Customs Court. ${ }^{94}$ Constance Baker Motley was the first black woman appointed to the federal trial bench anywhere. ${ }^{95}$ Look at the photograph of the Southern District of New York judges in 1966 in Motley, Equal Justice Under Law, before page $123 .{ }^{96}$ Can you imagine what it was like for her to be the only woman - and black woman!- in that group? Moreover, Judge Motley was not only the sole woman and the sole black who was a judge, but also one of the very few women who held any professional job at the courthouse and one of the very few blacks who held any job at the courthouse. Kristin Booth Glen recalled that when she "graduated to a federal clerkship there were few women clerks, no women judges on the Second Circuit, and only one, Constance Baker Motley," on the Southern

88. See PARTing the WATERs, supra note 48 , at 818 , 824-25.

89. MotLEy, supra note 1 , at 180.

90. Id. at 205 .

91. Id. at 150 .

92. Id. at 151 .

93. Id.

94. SMith, supra note 24, at 44-45; see also Miriam Goldman Cedarbaum, Women on the Federal Bench, 73 B.U. L. REV. 39, 40 (1993).

95. Walter J. Walsh, Speaking Truth to Power: The Jurisprudence of Julia Cooper Mack, 40 How. L.J. 291, 297 (1997).

96. MotLey, supra note 1, 122-23. 
District of New York. ${ }^{97}$ Judge Motley also recalled that when she became a judge there was only one black employee at the federal courthouse and it was several years before a second was hired. ${ }^{98}$ "In fact," she said in an interview in 1992, "[t]oday, you can still count the Black employees on one hand," and "there are very few Black lawyers who have ever even appeared in this court." 99

Although Judge Motley's appointment to the district court can be told as a tale of triumph, it also is a tale of gender discrimination. She has told us that President Johnson initially planned to submit her name for a seat on the U.S. Court of Appeals for the Second Circuit to replace Thurgood Marshall, who had been appointed Solicitor General, but the opposition was so great that President Johnson nominated her for the district court instead. ${ }^{100}$ She said the opposition was based largely on her being a woman and was led by the Chief Judge of the Second Circuit, Judge Edward Lumbard. ${ }^{101}$ Since Thurgood Marshall already was sitting on the Second Circuit, it does seem more likely that opposition was based on gender than on race. Judge Motley wrote:

But Lumbard and others on the Second Circuit didn't want any women in this milieu. New York was the real power center of the whole circuit, which also includes Connecticut and Vermont, because there you had all the great commercial cases and so forth. Their attitude, pure and simple, was that a woman had no business being there. ${ }^{102}$

She continued to be the only woman on that court for twelve years, until 1978, when President Carter appointed Mary Johnson Lowe to the bench of the Southern District of New York. ${ }^{103}$ Judge Motley was Chief Judge of that court from June 1982 until October 1986, when she took senior status. ${ }^{104}$ She was only the second woman to serve as Chief Judge of a federal district court-and the Southern District of New York is the largest federal trial court in the United States. ${ }^{105}$ She was not immune from insult even while on the federal bench. She told the story of her introduction at a school for new federal judges:

97. Glen, supra note 57 , at 1697.

98. WASHINGTON, supra note 3, at 130.

99. Id. Judge Motley is quoted as saying both that there were no black employees at the courthouse when she became a judge and that when Thurgood Marshall became a circuit judge in 1962 , there was one black employee. Id. Since these statements seem inconsistent, I have taken the more conservative view, that there was one black employee in 1966. Had I needed a reminder of the unreliability of memoirs, preparing this speech and article would have served that function well.

100. Id. at 128. In the Linn Washington interview, Judge Motley said that Lyndon Johnson actually submitted such a nomination and then "had to withdraw" it, but her autobiography stated that President Johnson contemplated the nomination to the Second Circuit but did not make it. MotLEy, supra note 1, at 212.

101. MotLEY, supra note 1 , at 222.

102. WASHINGTON, supra note 3, at 129.

103. Id. at 144 .

104. Id.

105. $I d$. 
[T] he chairman of the group, who was a federal judge ... introduced each new judge at the meeting. In doing so, he told those assembled about how great each new judge was, how each had distinguished himself in the law. When it came to introducing me, he said simply that I had been on the Board of United Church Women, and I had been on the Board of the YWCA, and that was it. Former Supreme Court Justice Tom Clark, who was co-chairman of the meeting, grabbed the microphone and said, "Just a minute Mr. Chairman, I would like to say something about Mrs. Motley. She has appeared in our court and argued, I don't know, twenty cases." I said, "No, it's only ten."106

Judge Motley experienced a similar insult at her first Circuit conference and reported a similar slight to Robert Carter, who joined the Southern District of New York bench in 1972. ${ }^{107}$ She told other stories — of being greeted as "Mrs. Hastie" at a Patent Lawyers Association dinner at which the only blacks were herself and the guest speaker, Judge William $\mathrm{H}$. Hastie of the Third Circuit. ${ }^{108}$ At a meeting of the Lawyers Club, she took the elevator to the assigned floor, twenty, but was told by the young, white, male operator: "No women on twenty" and taken to a dark and empty twenty-first floor, from which a member of the club rescued her. ${ }^{109}$ Recalling these events, she said: "There are people who long for the good old days. I do not." 110

Judge Motley said she never was "appointed to any committee by the chief judge of the court of appeals." 111 Men with less seniority were appointed, but she was not, although Thurgood Marshall pushed for her appointment. ${ }^{112}$ Judge Motley had what she called "an amusing experience" when she first joined the Southern District of New York bench:

We used to have the judges' dinners for our district at the Century Club in Manhattan, two or three times a year. ... [T] he Century Club didn't allow women to go up to the second floor. In fact, the club didn't have any women members until a few years ago. When I came on the bench my fellow judges wondered how in the world they were going to get me upstairs. So, they got up this ruse: They told the club people I was a secretary and that I had to take the minutes of the meeting. I guess the club people didn't want any trouble, didn't want to buck the judges, so they didn't say anything. I'm sure the maitre d' who waited on us and made the arrangements for the dinner knew I wasn't a secretary. And the

106. Sмiтh, supra note 24 , at 44 .

107. MotLey, supra note 1, at 223 ("In introducing Bob, however, Judge Moore simply said: 'And now I give you Bob Carter, former general counsel of the NAACP.'”).

108. Id. at 224 .

109. Id.

110. Id.

111. WASHINGTON, supra note 3 , at 130.

112. Id. 
Black guys who worked in the coat room and opened the door, they were amused. They knew I wasn't supposed to be up there, so they would just laugh and smile every time they saw me. ${ }^{113}$

She also was the subject of a recusal motion "filed by a defendant law firm in a case in which a female lawyer was suing the law firm for gender discrimination under Title VII." 114

In her years on the bench, she decided more than 2500 cases and rendered a number of important decisions. ${ }^{15}$ She attacked the use of peremptory challenges. ${ }^{116}$ Judge Motley also proposed that the right to adjudicate Title VII claims in a judicial forum may be not only fundamental, but inalienable. ${ }^{117} \mathrm{In}$ 2000, she "ordered the City [of New York] defendants to submit . . . a remedial plan "for providing full and complete educational facilities and services to all eligible Rikers Island inmates." 118 And she invalidated the baseball commissioner's policy of excluding female sports reporters from locker rooms in city owned stadiums. ${ }^{119}$

\section{CONCLUSION}

Constance Baker Motley led an amazingly courageous, trailblazing, justicemaking life. She is far less well-known than she should be. But, as she wrote in her autobiography, "Becoming a part of history is a special experience ... nobody can take it away from you. You may be forgotten, but it's like immortality: You will always be there. ${ }^{\prime 20}$ She is right. Constance Baker Motley has earned her immortality. She - and the great good work she has done- "will always be there." 121

113. Id. at 142 .

114. Sherrilyn A. Ifill, Judging the Judges: Racial Diversity, Impartiality and Representation on State Trial Courts, 39 B.C. L. REV 95, 116 (1997).

115. WASHINGTON, supra note 3, at 143.

116. See Minetos v. City Univ. of N.Y., 925 F. Supp. 177, 181-85 (S.D.N.Y. 1996).

117. See Karen Halverson, Arbitration and the Civil Rights Act of 1991, 67 U. CIN. L. Rev. 445, 486-87 (1999).

118. Handberry v. Thompson, 219 F. Supp. 2d 525, 530 (S.D.N.Y. 2002).

119. See Ludtke v. Kuhn, 461 F. Supp. 86 (S.D.N.Y. 1978).

120. MotLEy, supra note 1, at 106.

121. Id. 